\title{
EFFICACY OF BORTEZOMIB PLUS DEXAMETHASONE AS A FIRST LINE TREATMENT IN NEWLY DIAGNOSED CASES OF MULTIPLE MYELOMA: A SINGLE CENTRE STUDY IN A TERTIARY CARE HOSPITAL
}

\author{
SHARMIN $\mathrm{M}^{1}$, ISLAM MM ${ }^{2}$, AZIZ A $^{3}$, SHAH $\mathrm{S}^{4}$, RAHMAN MJ ${ }^{5}$, KABIR ASMA ${ }^{6}, \mathrm{KABIR} \mathrm{A}^{7}$, \\ HASAN MR ${ }^{8}$, RAHMAN F ${ }^{9}$, KABIR SMH ${ }^{10}$, AZAD KAK ${ }^{11}$
}

\begin{abstract}
Background: Multiple Myeloma (MM) accounts for 1\% of malignant tumors and $10 \%-15 \%$ of hematopoietic neoplasms. Bortezomib, a first in class proteasome inhibitor, induces apoptosis and growth arrest and reverse chemoresistence in Myeloma cell and has demonstrated no irreversible adverse effect on haemopoietic stem cell. Dexamethasone increases the response rate. Thus, Bortezomib plus dexamethasone represent highly effective regimen for previously untreated Multiple Myeloma cases and significantly higher response rates approximately 70\%90\% have been observed. This combination thus may serve the basis of future strands of care in Multiple Myeloma patients.

Objective: The aim of the study was to assess the efficacy, safety and tolerability of Bortezomib in newly diagnosed cases of Multiple Myeloma patients in Bangladesh.

Materials \& Methods: This prospective observational study was carried out in the Haematology department of BSMMU from June 2017 to December 2018. Patients received inj. Bortezomib $\left(1.3 \mathrm{mg} / \mathrm{m}^{2}\right) 4$ cycles as an intravenous bolus on days $1,4,8,11$ in a three week cycle (twice weekly administration) in indoor and same patients as day care basis in outpatients department. Dexamethasone at $40 \mathrm{mg}$ was given intravenously or orally on the day of and day after inj Bortezomib.A self administered questionnaire containing different set of questions regarding Multiple Myeloma were used for data collection.

Results: Among the study population, 93\% of patients had anaemia followed by bone pain (86\%) and renal impairment (39\%). Out of 25 patients, complete response achieved in 13 patients (52\%), where 4 patients(16\%) showed partial response, 6 (24\%) showed very good partial response and $2(8 \%)$ patients showed no response. The overall response rate was 92\% belonged to partial,very goofd partial and no respone respectively. Death occurred in 3 cases (12\%). 5 patients (20\%) developed Bortezomib induced peripheral neuropathy. Life threatening intracranial haemorrhage occurred in two patients (8\%). Death occurred in 3 cases (12\%), 2 patients due to intracranial haemorrhage and another from cardiac arrest. In this study, S. creatinine, â2 microglobulin and bony lesion variables showed significant association with treatment response.

Conclusion: Bortezomib plus dexamethasone is a highly effective and safe regimen for previously untreated multiple myeloma patients. This novel therapy in myeloma represent a new trearment paradigm targeting both tumor and microenvironment which has markedly improve overall response(OR), long progression free survival (PFS) and overall survival (OS)across in all risk groups. Moreover, it can be administered safely in the outpatient setting provided by clinicians.
\end{abstract}

Key Words: Bortezomib, Proteasome inhibitors

1. Dr. Mahbuba Sharmin, Medical Officer, Dept. of Haematology, Bangabandhu Sheikh Mujib Medical University, Dhaka

2. Dr. Mohammad Manirul Islam, Assistant professor, Haematology, Department, Dhaka Medical College, Dhaka.

3. Dr. Abdul Aziz, Professor and Chairman, Haematology Dept., Bangabandhu Sheikh Mujib Medical University Dhaka.

4. Dr. Salauddin Shah, Associate Professor, Haematology Department, Bangabandhu Sheikh Mujib Medical UniversityDhaka

5. Prof. Dr. Md. Jalilur Rahman, Ex-Chairman, Haematology Dept., Bangabandhu Sheikh Mujib Medical University, Dhaka.

6. Dr. ASM Anwarul Kabir, Registrar, Holy family Red Crescent Medical College and Hospital, Dhaka

7. Dr. Amin Lutful Kabir, Associate Professor, Haematology Department, Bangabandhu Sheikh Mujib Medical University (BSMMU), Dhaka.

8. Md. Rashedul Hasan, Assistant Professor of Medicine, Green Life Medical College Hospital, Dhaka

9. Dr. Farzana Rahman, Assistant Professor of Haematology, BSMMU, Dhaka

10. Dr. SM Humayun Kabir, Assistant Professor, Department of Radiation Oncology, National Institute of Cancer Research and Hospital (NICRH), Dhaka

11. Prof. Khan Abul Kalam Azad, Professor and Head, Department of Medicine, Dhaka Medical College, Dhaka

Correspondence: Dr. Mahbuba Sharmin, Medical Officer, Haematology department, Bangabandhu Sheikh Mujib Medical University (BSMMU), Dhaka. Email:dr.sharmin1012@gmail.com, Mob:+8801717664554 


\section{Introduction:}

Multiple Myeloma is the second most common haematological malignancy with an estimated annual incidence of approximately 75,000 cases worldwide. ${ }^{1-14}$ The survival ranges from few months to more than 10 years with the availability of novel agents such as thalidomide, lenalidomide, and bortezomib over recent years. ${ }^{1-7,9,13,16}$. Multiple Myeloma is a B-cell malignancy characterized by accumulation of terminally differentiated clonal plasma cells in the bone marrow, the production of a monoclonal immunoglobulin detectable in the serum and/or urine and the presence of lytic bone lesions. ${ }^{1-7}$ The clinical manifestation of Myeloma are heterogeneous and include bone complications, symptoms of impaired haemopoiesis and hyperviscosity, renal dysfunction, infection, peripheral neuropathy and extra medullary disease. ${ }^{2-11}$ Myeloma constituting $1 \%$ of all cancer but it is the second most common blood cancer after Lymphoma and account for $15 \%$ of Haematological malignancies. ${ }^{2-7,9,13}$ The incidence of Multiple Myeloma has been reported to be increasing, but it probably reflects increasing diagnostic accuracy ${ }^{1-9}$. The median age at diagnosis is 6575 yrs. ${ }^{7}$ Myeloma seems to be more common in men than women. ${ }^{1-11,13-16}$ The etiology of the disease is unknown but it is more common in certain racial groups such as those of AfroCaribbean origin ${ }^{2}$.

The Myeloma cell is a post germinal centre plasma cell that has undergone immunoglobulin class switching and somatic hypermutation and secretes the paraprotein i.e. present in serum ${ }^{3-10}$. M protein[M component, Myeloma protein or M spike] is a hallmark of disease. $97 \%$ of Myeloma patient have an intact Immunoglobulin or a free light chain that can be detected by protein electrophoresis $4,6,8-13,15$. Diagnostic workup may reveal a normochromic normocytic or macrocytic anaemia, marked rouleaux formation, neutropenia and thrombocytopenia in advanced disease, high ESR and C-reactive protein(CRP), monoclonal protein in serum or urine or both, increased abnormal plasma cell $>20 \%$ in the bone marrow, bone lesion, hypercalcemia, hyperuricemia, low serum albumin, renal impairment, etc.Serum â2 microglobulin is often raised and is a useful indicator of prognosis.Sensitivity to drugs and clinical course vary widely among patients ${ }^{5-13}$. At the current time, the disease remains incurable except for those very few, mostly younger patient who may be cured by allogenic stem cell transplantation. Rest of the modalities of treatment is various combination of chemotherapy, among them MP[Melphalan and Prednisolone] was probably the first line treatment for many years. But it induces partial remission in $50 \%$ patient, while complete remission(CR) is very rare.VAD (Vincristine, Adriamycin, Dexamethasone) has significant CR rate but its toxicities are sometimes intolerable. The response rate of VMCP (Vincristine, Melphalan, Cyclophosphamide and Prednisolone) is not so much optimistic and above all resistance rate is high 2-7,9-16. $^{2}$

Bortezomib is a first in class proteasome inhibitor,induces apoptosis and growth arrest and reverse chemo-resistance in Myeloma cell and has demonstrated no irreversible adverse effect on Haemopoietic stem cel11-7,911,13 . Bortezomib is usually given as a short intravenous infusion on days $1,4,8,11$ of a 3 weekly cycle on an outpatient basis. but it is used as induction agent for its effectiveness and clinical trial results The 72 hour gap between infusion is important to allow recovery of the proteasome inhibition in the normal cell. The ten day treatment free period allows cell recovery and prevents excessive side-effect. A total upto 4-6 cycle may be given depending on response and toxicities ${ }^{7}$.

Bortezomib therapy is costly regimen for our general population. Unfortunately, in our country no such organized and structured clinical trial of response of Bortezomib and dexamethasone in newly diagnosed cases of Multiple Myeloma have been carried out. The present clinical study will reflect the response of Bortezomib and dexamethasone in newly diagnosed cases of Multiple Myeloma patient in Bangladesh.

\section{Materials and Method:}

A prospective observational study was conducted over the period of 18 months from 
June 2017 to December 2018 in Bangabandhu Sheikh Mujib Medical University .Actual sample size was 30 newly diagnosed case of multiple myeloma. Among them 5 patients discontinue treatment, so final sample size was 25 . Diagnosis of all the patients based on S.protein electrophoresis, bone marrow examination with proper leishman staining and radiological findings. Fulfilling the criteria for entry into the study detailed clinical history, physical examinations \& relevant investigations were recorded in data sheet. After approval of study protocol by the Institutional Ethics Committee of Bangabandhu Sheikh Mujib Medical University(BSMMU) and after taking written informed consent, these patients were enrolled in this study.

\section{Inclusion criteria:}

- Newly diagnosed Multiple Myeloma

- Patient age 42-75 years,

- Platelet count=100x 109/ L

- $\quad$ Absolute Neutrophil count $=1 \times 10^{\circ} 9 / \mathrm{L}$

- Corrected Serum Calcium $=14 \mathrm{mg} / \mathrm{dl}$

- $\quad$ Serum Hepatic Amino Transferase level =2.5 $\mathrm{x}$ the upper limit of normal. Normal value$7-56 u / d l$ of serum

- Total Bilirubin =1.5 x upper limit of normal. Normal value- $0.2-1.2 \mathrm{mg} / \mathrm{dl}$ and Creatinine clearance $=30 \mathrm{ml} / \mathrm{min}$.

- Patient willingly given informed consent to take part in this study.

\section{Exclusion Criteria:}

- Patient of attendant unwillingly to give informed consent to take part in this study

- Age $>75$ years of newly diagnosed case of Multiple Myeloma

- Relapsed or refractory Multiple Myeloma patient

- Confirmed Amyloidosis.

- HIV positivity

- History of other malignancy, uncontrolled Diabetes, Grade $=2$ Peripheral Neuropathy (National Cancer Institute)

Data were collected using a preformed data collection sheet (questionnaire) according to the above mentioned criteria.Diagnosis of all the patients based on S.protein electrophoresis, bone marrow examination and radiological findings. After fulfilling the criteria for entry into this study patients were treated with inj. Bortezomib $\left(1.3 \mathrm{mg} / \mathrm{m}^{2}\right)$ as an intravenous bolus on days $1,4,8,11$ in a three week cycle(twice weekly administration) in indoor and same patients as day care basis in outpatients department. Dexamethasone at 40mg was given intravenously or orally on the day of and day after inj Bortezomib.Anti-platelet drug (to prevent the risk of thromboembolism), antibiotic (for infection) and red cell concentrate transfusion (if hemoglobin less than $8 \mathrm{gm} / \mathrm{dl}$ ) were given as necessary. Most of the patients received variable number of zolendronic acid with each cycle of Bortezomib and dexamethasone.

\section{When to stop Bortezomib}

- Hypersensitivity to bortezomib and discontinue therapy immediately.

- Cough and SOB

- Bloody Vomiting

- Bloody Diarrhoea

- Peripheral neuropathy

\section{Follow-up time-}

- Indicates time between initiation of Bortezomib and the date of last follow-up.

\section{Follow-up Schedule-}

- Every 21days interval for 6 months

\section{Assessment of response:}

S.protein electophoresis and bone marrow examination were done after 4 cycles of Bortezomib and dexamethasone for final assessment of responses with the following criteria. In this study we used international Myeloma Group (IMWG) criteria to assess the response to anti-myeloma.

\section{Response to therapy-Indicate}

- complete response (CR)

- Partial response (PR)

- Very good partial response(VGPR)

- $\quad$ Non- responder (NR) 
Complete response was defined as absence of $M$ protein in serum or urine protein electrophoresis, the absence of plasmacytoma and $<5 \%$ plasma cells in the bone marrow.

Partial response was defined as $>50 \%$ reduction of plasma cells in bone marrow and absence of $M$ protein in the serum and absence of urinary Bence jones protein.

Very good partial response (VGPR) was defined as $\geq 90 \%$ decrease in serum $M$ - protein.

No-response was defined as $<50 \%$ reduction of plasma cells in the bone marrow or presence of $M$ protein in the serum or presence of urinary Bence jones protein.

\section{Time to obtain response:}

Indicates time between the initiation of Bortezomib and dexamethasone and the date of completion of 4 cycles Bortezomib.

\section{Statistical analysis:}

Data were analyzed using the Package for the Social Science (version 19.0).A total 30 new diagnosed patients of Multiple Myeloma were taken for induction therapy with Bortezomib and dexamethasone. Among them 5 patient discontinue treatment, so final sample size was 25 . Base data were recorded before treatment and follow up were recorded at 6 and 12 week.

\section{Results:}

25 adult Multiple Myeloma patients were included in this study who were in age group from 42- 75 years. The mean age was 58.04 (SD \pm 6.45$)$ and median was 56.

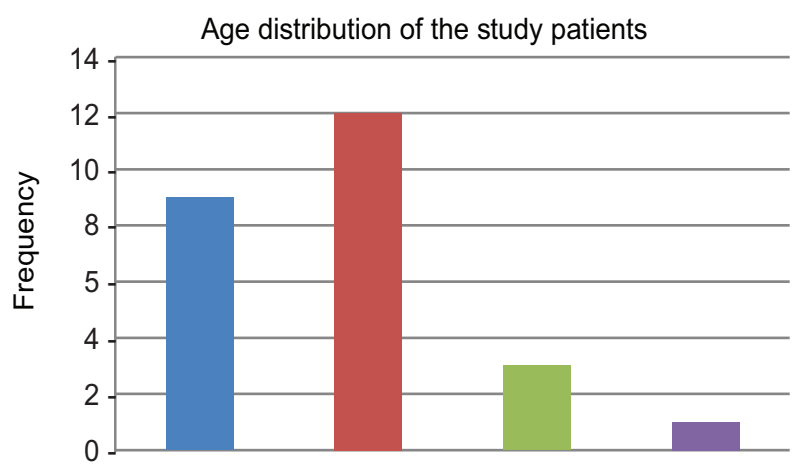

Fig.-1: Bar diagram showing age distribution of study patients.
Among the 25 patients $15(66 \%)$ were male and $10(40 \%)$ were female. The male to female ratio was $1.5: 1$.

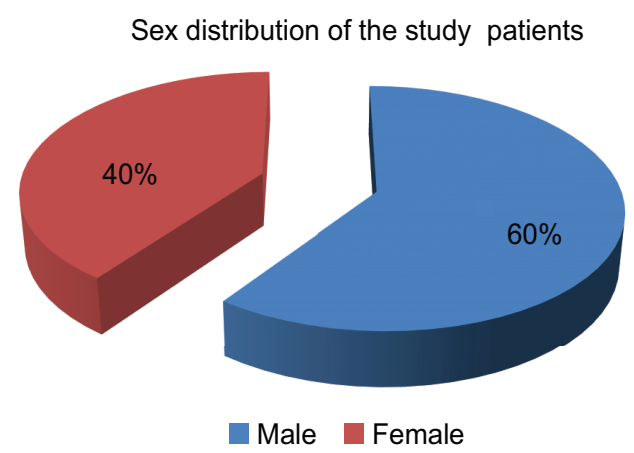

Fig.-2: Pie chart showing sex distribution of the study patients

Most of the patients were businessmen (40\%). other frequent occupation was house wife $(28 \%)$, service holder $(20 \%)$ and doctor, farmer \& teacher were $1 \%$ each.

\section{Occupation of the study patients}

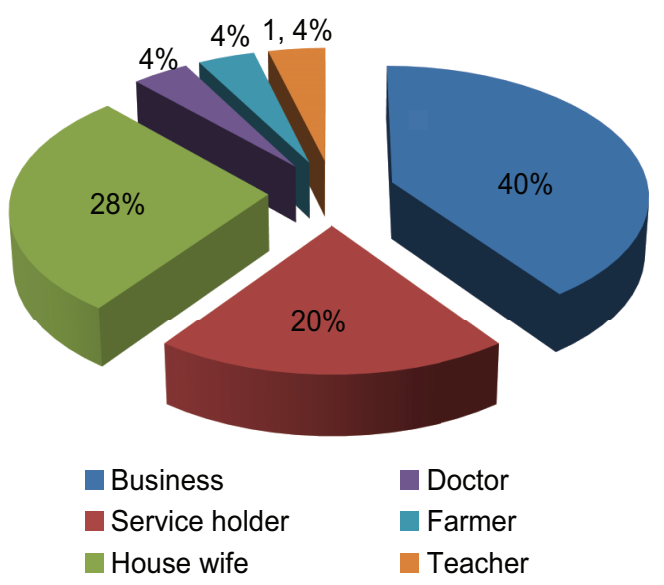

Fig.-3: Pie chart showing occupation distribution of the study patients

All patient had weakness(100\%), most of the patient had anaemia(96\%) and bone pain(88\%). Infection and renal impairment, weight loss were $40 \%, 36 \%$ and $28 \%$ respectively. Only one (4\%) had neuropathy.(Shown in table-1) 
Table-I

Descriptive statistics of clinical signs and symptoms of the patient $(n=25)$

\begin{tabular}{lcc}
\hline Variable & Frequency & Percentage $(\%)$ \\
\hline Weakness & 25 & 100 \\
Weight loss & 7 & 28 \\
Bone pain & 22 & 88 \\
Infection & 10 & 40 \\
Neuropathy & 01 & 04 \\
Renal impairment & 09 & 36 \\
Anaemia & 24 & 96 \\
\hline
\end{tabular}

At diagnosis, mean of Hemoglobin, Total leucocyte count, platelets, S. creatinine, S. albumin, S. calcium and â2 microglobulin, Lactate dehydrodenage(LDH) and Bone marrow plasma cell,serum M protein were $8.22 \mathrm{gm} /$ d1,8.5 thousands/ $\mu 1,2.551 \mathrm{lacs} / \mu 1,2.25 \mathrm{mg} /$ $\mathrm{d} 1,28.12 \mathrm{~g} / \mathrm{L}, 9.65 \mathrm{mg} / \mathrm{d} 1 \& 4.55 \mathrm{mg} / \mathrm{L}, 213 \mathrm{IU} /$
L, $69 \%, 76 \%$ respectively. At 6 weeks mean Hemoglobin,Total leucocyte count,platelets, S. creatinine, S. albumin, S. calcium and â2 microglobulin, Lactate dehydrodenage(LDH), serum $M$ protein were $11.67 \mathrm{gm} / \mathrm{d} 1,10.11$ thousands / $\mu 1,2.10$ lacs / $\mu 1,1.64 \mathrm{mg} / \mathrm{dl}, 31.24 \mathrm{~g} /$ L, $9.32 \mathrm{mg} / \mathrm{d} 1 \& \quad 3.52 \mathrm{mg} / \mathrm{L}, 193 \mathrm{IU} / \mathrm{L}, 46 \%$ respectively But at 12 week mean of Hemoglobin,Total leucocyte count,platelets, S. creatinine, S. albumin, S. calcium and â2 microglobulin,Lactate dehydrodenage(LDH), Bone marrow plasma, cell and serum $\mathrm{M}$ protein were $11.95 \mathrm{gm} / \mathrm{dl}, 11.23$ thousands $/ \mu 1,1 . .81$ lacs / $\mu 1,1.45 \mathrm{mg} / \mathrm{dl}, 34.36 \mathrm{~g} / \mathrm{L}, 9.10 \mathrm{mg} / \mathrm{dl} \&$ $2.7 \mathrm{mg} / \mathrm{L}, 152 \mathrm{IU} / \mathrm{L}, 11 \%, 13 \%$ respectively. Mean ESR before chemotherapy was $94.76 \mathrm{~mm}$ in Ist hour, where after treatment at 6 weeks and 12 weeks were 32 and $17.30 \mathrm{~mm}$ in Ist hour respectively. Before treatment, mean $\mathrm{Hb}$ concentration was only $8.22 \mathrm{~g} / \mathrm{dl}$ which was increase to $11.67 \mathrm{~g} / \mathrm{dl}$ and $11.95 \mathrm{~g} / \mathrm{dl}$ at 6 and 12 weeks.

Table-II

Blood/Biochemical profile before and after Bortezomib plus Dexamethasone( $n=25)$

\begin{tabular}{lccc}
\hline $\begin{array}{l}\text { Parameter } \\
\text { (Mean value) }\end{array}$ & $\begin{array}{c}\text { Before regim } \\
\text { (at diagnosis) }\end{array}$ & $\begin{array}{c}\text { 6 weeks after } \\
(2 \text { cycles) regim }\end{array}$ & $\begin{array}{c}\text { 12 weeks after } \\
\text { (4 cycles) regim }\end{array}$ \\
\hline Haemoglobin(gm/dl) & 8.22 & 11.67 & 11.95 \\
TLC(thousaunds/ $\mu 1)$ & 8.5 & 10.11 & 11.23 \\
Platelets (Lacs/ $\mu \mathrm{L})$ & 2.55 & 2.10 & 1.81 \\
ESR & 94.76 & 32 & 17.30 \\
(mm in $1^{\text {st }}$ hour) & & & $1.45 \mathrm{~S}$. \\
S.Creatinine(mg/dl) & 2.25 & 1.64 & 34.36 \\
Albumin(g/dl) & 28.12 & 31.24 & 9.10 \\
S.Calcium(mg/dl) & 9.65 & 9.32 & 2.7 \\
B2 microglobulin(mg/l) & 4.55 & 3.52 & 152 \\
LDH(IU/L) & 213 & 193 & 11 \\
Bone marrow plasma & 69 & - & 13 \\
Cell (\%) & & 46 & 00 \\
S.M protein (\%) & 76 & 01 & \\
Urinary Bence Jones protein & 01 & & \\
\hline
\end{tabular}

19 patients $(76 \%)$ had serum monoclonal protein (M protein). It is reduced to $46 \%$ at 6 week and $13 \%$ at 12 week of treatment. Only one patient (4\%) had urinary Bence Jones protein which remained positive at 6 weeks but disappeared at 12 weeks of treatment.(shown in Table-II) 
Table-III

Descriptive statistics of toxicity of treatment $(n=25)$

\begin{tabular}{lcc}
\hline Toxicity & Frequency & Percentage \\
\hline Peripheral & 5 & 20 \\
Thrombosis & 0 & 0 \\
Constipation & 3 & 12 \\
Hyperglycaemia & 1 & 4 \\
Somnolence & 6 & 24 \\
Rash/Desquamation & 1 & \\
Intracranial & 2 & 8 \\
haemorrhage(ICH) & & \\
Cardiac arrest & 1 & 4 \\
Electrolyte imbalance & 1 & 4 \\
\hline
\end{tabular}

During treatment, 6 patients (24\%) suffered from somnolence and 5 patients $(20 \%)$ had Peripheral neuropathy. Three (12\%) patients complained of constipation and we found $4 \%$ of suffered from hyperglycaemia, rash, cardiac arrest and electrolyte imbalance. Life threatening intracranial haemorrhage occurred in two patients (8\%). Complete response achieved only 13 patients (52\%), where $4(16 \%), 6(24 \%)$ and $2(8 \%)$ patients belonged to partial, very goofd partial and no respone respectively (shown in Table-IV).

\section{Table-IV}

IMWG response rate after 4 cycles of chemotherapy $(n=25)$

\begin{tabular}{lcc}
\hline Type & No. of patients & $\%$ \\
\hline Complete response(CR) & 13 & $52 \%$ \\
Partial response(PR) & 4 & $16 \%$ \\
Very good patial & & \\
Response(VGPR) & 6 & $24 \%$ \\
No response(NR) & 2 & $8 \%$ \\
\hline The overall response rate was $92 \%$. (Table-4)
\end{tabular}

\section{Discussion:}

The mean age was 58.04 ( $\mathrm{SD} \pm 6.45)$ and median was 56 .Age ranged from $42-75$ years. These findings are a little bit lower than study done by Rajkumar et al (2005), Wolf and Sonneveld et al (2008), Dingli et al(2005). They found the median (range) age 65 (38-83), 59 (34-65) and $66(36-78) .{ }^{8}$ In the present study number of male was $15(60 \%)$ and female was $10(40 \%)$ and male to female ratio was $1.5: 1$. Sex ratio of the patient vary widely, the male -female ratio in studies by Rajkumar et al (2005), Wolf and Sonneveld et al (2008), Dingli et al (2005) are

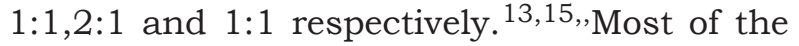
patients (40\%) were business men by profession; other frequent occupation was house wife( $28 \%)$, service holder $(20 \%)$ and doctor, farmer \& teacher were $1 \%$ each.

All of the patients (25) presented with weakness, followed by $86 \%$ patient had bone pain and $28 \%$ noticed weight loss. On examination, $93 \%$ of patient had anaemia, $40 \%$ had evidence of infection and renal impairment was found in 9 $(36 \%)$ cases. Only $1(4 \%)$ patient suffered from neuropathy. Where Khan MA, Sarker S, Kabir A, Hasan M, Haque M D (2002) found $100 \%$ of patient had bone pain, $77 \%$ had anaemia, 41\% had infection and $18 \%$ had renal impairment. ${ }^{11}$,

In this study population(25), mean ESR before chemotherapy was $94.76 \mathrm{~mm}$ in Ist hour, where after treatment at 6 weeks and 12 weeks were 32 and $17.30 \mathrm{~mm}$ in Ist hour respectively. Before treatment mean $\mathrm{Hb}$ concentration was only $8.22 \mathrm{~g} / \mathrm{dl}$ which was increase to $11.67 \mathrm{~g} / \mathrm{dl}$ and $11.95 \mathrm{~g} / \mathrm{dl}$ at 6 and 12 week. Where Khan MA, Sarker S, Kabir A, Hasan M, Haque M D (2002) showed $86.4 \%$ had high ESR $\left(>85 \mathrm{~mm}\right.$ in $1^{\text {st }}$ hour) and $82 \%$ of patient had $\mathrm{Hb}<10 \mathrm{gm} / \mathrm{dl} .{ }^{6}$

Among the study population, mean S. calcium before chemotherapy was $9.95 \mathrm{mg} / \mathrm{dl}$ which gradually went down to $9.18 \mathrm{mg} / \mathrm{dl}$ and $9.02 \mathrm{mg} /$ d1 at 6 week \& 12 week respectively. At diagnosis, mean of S. creatinine, S. albumin ,S.calcium and â2 microglobulin were $2.25 \mathrm{mg} /$ $\mathrm{d} 1,28.12 \mathrm{gm} / \mathrm{L}, 9.65 \mathrm{mg} / \mathrm{dl}$ and $4.55 \mathrm{mg} / \mathrm{L}$ respectively. But at 12 week mean were 1.45 $\mathrm{mg} / \mathrm{dl}, 34.36 \mathrm{gm} / \mathrm{L}, 9.32 \mathrm{mg} / \mathrm{dl} \& 2.7 \mathrm{mg} / \mathrm{L}$ respectively. In our study only 2 patient (8\%) had hypercalcaemia, where Khan MA et al (2002) found $18 \% .^{6-8,13 \text {, }}$

During treatment 6 patient (24\%) suffered from somnolence and $5(20 \%)$ had Peripheral neuropathy. Three $(12 \%)$ patient complained of constipation and we found $4 \%$ of suffered from 
hyperglyecaemia, rash, cardiac arrest and electrolyte imbalance. Life threatening intracranial haemorrhage occurred in two patient $(8 \%)$. SundarJagannath et al. found the most common adverse events sensory neuropathy $(31 \%)$, constipation $(28 \%)$, myalgia $(28 \%)$ and fatigue $(25 \%) .{ }^{13}$

Out of 25 patient,complete response achieved in 13 patients (52\%), where $4(16 \%), 6(24 \%)$ and $2(8 \%)$ patients belonged to partial,very good partial and no respone respectively. The overall response rate was $92 \%$. SundarJagannath et al. study showed response rate (CR + PR) was $88 \%$, with undetectable paraprotein (CR) in $6 \%$ and All 32 patients completed the first two cycles of Bortezomib alone, of whom 3\% achieved CR, 9\% VGPR, and 28\% PR . ${ }^{13}$. Three patient (12\%) died during treatment, 2 patient due to intracranial haemorrhage and another from cardiac arrest.

\section{Conclusion:}

Bortezomib plus dexamethasone is highly effective and well-tolerated regimen for frontline treatment of MM. This combination has markedly improve overall response(OR), long progression free survival (PFS) and overall survival (OS)across in all risk groups. Since the depth of response to treatment correlates with outcomes, both consolidation and maintenance therapies are now being employed to deepen the initial response and prevent relapse, respectively.

\section{Authors' contributions:}

Sharmin M designed the study,collected, analysed the data and wrote the first draft of the report.Aziz A, Shah S,Kabir AL, Rahman MJ were the principal supervisors, contributed to study design and provided expert clinical opinion. Akhter K,Rahman F:Evaluation and optimization of all patients with comorbid conditions, review of script and data analysis. : Kabir ASMA : Main persons for data entry,cleaning and analysis. All authors contributed to data interpretation and critical revising of the report.

\section{Acknowledgement:}

The authors would like to express their sincere gratitude to the participants of the
study,Haematology department, hospital administration team of Bangabandhu Sheikh Mujib Medical University(BSMMU) .

Funding: No funding sources

\section{Conflict of interest:}

All authors have nothing to disclose.

\section{Disclosures:}

The authors have no financial interests to disclose.

\section{References:}

1. A V Hoffbrand,DanialCatovsky, Edward G.D, Tuddenham: Post graduate haematology, $7^{\text {th }}$ ed, UK Blackwell Publishing Limited, 2016, p-577-598.

2. A V HoffbrandDanialCatovsky, Edward G.D, Tuddenham: Post graduate haematology, $6^{\text {th }} e d$, UK Blackwell Publishing Limited, 2011, p-681-701.

3. AV Hoffbrand, PAH Moss, JE Pettit: Essential haematology $5^{\text {th }}$ ed, UK, Black well publishing company, 2006, p-216-228.

4. Angela Dispenzieri, Martha Q lacy and Philip R. Gripp, Multiple Myeloma, Edited by John Grcer: Wintrobes clinical Haematology, Philadelphia, Lippincott, Williams and Wilkins, 2004, p-2584-88.

5. BarlogieB,Epstein J, Selvanauagam P, Alexanian R, Plasma cell myeloma-new biological insights and advances in therapy,blood,1989;73:865-879.

6. Jagannath,BGMDurie,J Wolf. Bortezomib therapy alone and in combination with dexamethasone for previously untreated symptomatic multiple myeloma.British Journal of Haematology. June 2005, 129(6):776-783.

7. Antonia Field-Smith, Gareth $\mathrm{J}$ Morgan and Faith $\mathrm{E}$ Davies.Bortezomib (Velcade ${ }^{\mathrm{TM}}$ ) in the treatment of Multiple Myeloma .TherClin Risk Manag. 2006 September; 2(3): 271-279.

8. Harousseau JL, Attal M, Avet-Loiseau H. The role of complete response in multiple myeloma.Blood.2009;114(15):3139-3146.

9. Kyle RA, Leong $\mathrm{T}, \mathrm{Li} \mathrm{S}$, et al. Complete response in multiple myeloma: clinical trial E9486, an Eastern Cooperative Oncology Group study not involving stem celltransplantation.Cancer.2006;106(9):1958- 1966.

10. van de Velde H, Liu X, Chen G, et al. Complete response correlates with long-term survival and progression-free survival in high-dose therapy in multiple myeloma.Haematologica.2007;92(10):13991406. 
11. Kastritis E, Zervas K, Symeonidis A, et al. Improved survival of patients with multiple myeloma after the introduction of novel agents and the applicability of the International Staging System(ISS): an analysis of the Greek Myeloma Study Group (GMSG). Leukemia. 2009;23(6):1152-1157.

12. Kumar SK, Rajkumar SV, Dispenzieri A, et al. Improved survival in multiple myeloma and the impact of novel therapies.Blood.2008;111(5):25162520.

13. Palumbo A, Rajkumar SV. Treatment of newly diagnosed myeloma.Leukemia.2009;23(3):449-456.
14. San Miguel JF, Schlag R, Khuageva NK, et al.Bortezomib plus melphalan and prednisolone for initial treatment of multiple myeloma.NEngl J Med.2008;359(9):906-917.

15. Richardson PG, Sonneveld P, Schuster MW, et al. Bortezomib or high-dose dexamethasone for relapsed multiple myeloma.NEngl J Med.2005;352(24):24872498.

16. Dimopoulos M, Spencer A, Attal M, et al. Lenalidomide plus dexamethasone for relapsed or refractory multiple myeloma.NEngl J Med.2007; 357(21):2123-2132. 